\title{
Üniversite Öğrencilerinde Dinin Etkisi ile Tüketici Karar Verme Tarzları Arasındaki İlişki*
}

\author{
Murat SEYFi' ${ }^{* *}$, Merve ÇERÇ I $\dot{I}^{* * *}$
}

\begin{abstract}
Öz
Küreselleşme ve artan rekabet ortamında tüketici davranışlarının belirlenmesine yönelik birçok sınıflandırma çalışmaları yapılmaktadır. Dinsel etkilerde sadece kişilerin dini yaşam alanlarını değil aynı zamanda din dışı başka davranışlarını biçimlendirdiği için tüketici karar verme süreçlerinde etkisinin araştırılması oldukça önemli bir konudur. Bu çalışmanın amacı gençlerin dinsel etkileri hissetme düzeyleri ile tüketim tarzları arasındaki ilișkiyi incelemektir. Bu bağlamda Tüketici Karar Verme Tarzları ve Gençlerin Dinsel Etkiyi Hissetme Düzeyleri ölçekleri kullanılarak İstanbul ve Tokat'da yaşayan gençlerin katılımıyla bir anket araștırması yürütülmüştür. Elde edilen veriler ile yüzde ve frekans hesapları, ilişkisiz grup t testleri, pearson çarpım moment korelasyonu, regresyon analizleri yapılmıştır. Araştırma sonuçları ve sınırlılıkları tartışılmıştır.
\end{abstract}

Anahtar Kelimeler: Küreselleşme, Dinsel Etkiler, Tüketici, Tüketici Davranışları, Tüketici Karar Verme Tarzları

The Relationship Between the Influence of Religion and Decision Making Styles of Consumers Among University Students

\footnotetext{
Abstract

Various studies are being conducted regarding the determination of consumer behaviour in the era of globalization and increasing competition. Since religious influences not only structure the individuals' religious life settings, but also their behaviours other than religion, it is important to investigate religion's impact on consumer decision-making processes. The aim of this research is to analyse the relationship between the levels of young people's religious influences and consumer styles. In this regard, by using Consumer Styles Inventory and The Levels of Young

Özgün Araştırma Makalesi [Original Research Article)

Geliş Tarihi: 09.01.2017 Kabul Tarihi: 15.05.2017

DOI: http://dx.doi.org/10.17336/igusbd.284708

* Bu çalışma TÜBİTAK'ın katkıları ile hazırlanmıştır.

** Yrd. Doç. Dr., Gaziosmanpaşa Üniversitesi, Niksar Uygulamalı Bilimler Yüksek Okulu, Halkla İlişkiler ve Reklamcılık Bölümü, Tokat, Türkiye, E-posta: seyfi.murat@gmail.com ORCID ID http://orcid.org/0000-0002-7188-235X

${ }^{* * *}$ Ar. Gör., Marmara Üniversitesi, Halkla İlișkiler Bölümü, İstanbul, Türkiye, E-posta: merve.cerci@marmara.edu.tr
} 
Sayfa/Page | 186

İGÜ Sos. Bil. Derg.,

4 (2), 2017,

ss. $185-200$.

People's Feeling Religious Effects as scales, a survey has been applied with the participation of young people at Istanbul and Tokat. With the data received, the calculations of percentage and frequency, independent group $t$ tests, Pearson Moment Correlation, regression analysis have been conducted. Lastly, the results and the restrictions of the research have been discussed.

Keywords: Globalization, Religious Effect, Consumer, Consumer Behaviour, Style of Consumer Consumption Decisions

\section{Giriș}

İletişim teknolojilerindeki gelişmeler ve küreselleşmenin etkileri ile tüketici davranışları çok hızlı bir şekilde değişmekte ve gelişmektedir. Son yıllardaki çalışmalar özellikle din ile ilgili değerlerin günlük tüketim alışkanlıklarını doğrudan etkilediğini göstermiştir. Özellikle firmalar dini değerleri ön plana çıkaran markalar yaratmaya odaklanmıştır. Örneğin İslami inançlara göre tasarlanmış "Helal" yiyecekler müşteri sadakati ve memnuniyeti açısından önemli bir öğe olmuştur. $\mathrm{Bu}$ yüzdende ürün ve dindarlık ile ilgili bilgiler yeni iletişim araçları ile hedef kitleye ulaşmakta ve bireylerde davranış değişikliği yaratmaktadır. Şirketler tüketicilerin inançları ile yaratılan markanın inançlarını eşleştirme çabasına girmiştir.

$\mathrm{Bu}$ çalışma hiperrekabet ortamında müşteri memnuniyeti ve sadakatini etkileyen faktörlerin dinsel boyutunun tespit edilmesi açısından önemli bir çalışmadır. Türkiye'de yapılan çalışmalara baktığımızda hipotez üretmekten ziyade alan araştırması niteliğinde yapılan çalışmalar olduğu görülmektedir. Bunun da temel nedeni alanda çok fazla çalışma olmamasıdır. Bu çalışma bundan sonra yapılacak olan hipotezler için bir temel oluşturacaktır.

Bu çalışmanın amacı gençlerin tüketim alışkanlıklarında dinin ne derece etkili olduğunu tespit etmek ve demografik özellikleri ile ilişkisini açıklamaktır. Konu ile ilgili yurtdışında birçok çalışma yapılmış iken ülkemizde bu alanda yapılan çalışmalar yok denecek kadar azdır. Çalışma kapsamında tüketici karar verme tarzları ve dindarlık arasındaki etkinin ne oranda olduğunu tespit etmek amacıyla regresyon testleri yapılmıştır. $\mathrm{Bu}$ bağlamda çalışmamız yurtiçinde yapılan çalışmalardan ayrılmakta ve literatüre yeni bir bakış açısı katmaktadır. Yapılan istatistiksel analizler sonucunda dindarlığın tüketim davranışlarını etkileme düzeyi tartışılmıştır.

\subsection{Din Kavramı}

Din kavramının temelinde "bağlanmak" vardır. Bu bağlanma dinin temeli kutsal kitaba ve peygamberinin davranış ve sözlerine dayanmaktadır. Amacı ise "değerlerin" hayata geçirilmesidir. Bu değerler, doğruluk, dürüstlük, iyi ahlak gibi temel değerlerdir. ${ }^{1}$ Delener'e göre; Din, kutsal olana yönelik

${ }^{1}$ Niyazi Öktem, Laiklik Din ve Alevilik Yazıları, Der Yayınları, İstanbul, 1995, s.30. 
birleşik bir inanç ve uygulama sistemi olarak tanımlanırken, dindarlık ise, belirli dini değerleri insanlar tarafından uygulanma derecesi olarak tanımlanmaktadır.2 Ayrıca din yaşamın akışını doğrudan etkileyen hakikatlar sistemi ile doğrudan ilişkilidir. Hakikatler bağlamında karşımıza çıkan din kavramı, insanın iç dünyasını etkileme özelliğine sahiptir. Bu etkileme ise yaşanılan çevre ile doğru orantılıdır. ${ }^{3}$ Tüm insanlık tarihi boyunca insanların sosyal ve ekonomik yaşantılarını etkilenmiş bir olgu olan din, bu nedenledir ki ekonomik faaliyetlerden ayrı düşünülmesi mümkün değildir. ${ }^{4}$ Birçok araştırmacı din ile satın alma davranışları arasında anlamlı ilişki olduğunu savunmuștur. ${ }^{5}$ Tabii ki her dinin kendine has özelliklerinin olmasından dolayı, tüketiciler üzerindeki etkileri de farklılık göstermiştir. Bununda temelinde her dinin hayatı yorumlama noktasında kendi dinamiklerinin olması yatmaktadır. Örneğin İslam dinine göre, "insan muhakeme yeteneği, özbilinçlik ve iradeli seçim" ile yaratılmıştır.6 İnsanının doğasına aykırı bir özellik taşımayan İslam dini, iktisadi hayatta karşılaşabilecek sorunları çözmeye yönelik kuralları barındıran, değişmez ilkelerinin yanında zamana ve koşullara göre yorumlanabilir özelliğe sahip bir dindir. $\mathrm{Bu}$ hali ile de problemlerin çözümlerine katkı sağlamaktadır.7

Dinin birtakım işlevleri bulunmaktadır. Toplumun normlarına ve değerlerine meşruluk kazandırarak sosyalleşme işlevine sahiptir. Bu değer ve normlara uyulması için sahip olunan birtakım kurallar eşliğinden sosyal kontrol sağlar. Ayrıca bu değerler arasında bir hiyerarşi yaratarak değerler hiyerarşisi sağlama işlevine de sahiptir. Bunların yanı sıra dayanışma işlevine sahiptir. Davranışlara meşruluk kazandırma işlevine sahiptir. İnananlarına zihniyet ve kimlik kazandırır. İç uyumu ve tutarlılığı sağlayarak ontolojik doyum sağlar. ${ }^{8}$ Bu yüzden din sadece Allah'a inanma süreci değil, bir yaşam biçimidir.

\subsection{Din Perspektifinde Tüketim Olgusu}

Ekonomi literatüründe tüketim; bedel karşıllğı satın alınan mal ve hizmetler ile hissedilen ihtiyacın karşılanması olarak tanımlansa da, tüketim yalnızca ekonomik bir süreçten ibaret olmayarak, üretim ile yok etme

\footnotetext{
${ }^{2}$ Nejdet Delener, "The Effects of Religious Factors on Perceived Risk in Durable Goods Purchase Decisions" Journal of Consumer Marketing, 1990, 7(3), 1990, 27-38

3 Öktem, a.g.e., s. 29.

${ }^{4}$ Werner Sombart, Kapitalizm ve Yahudiler, çev. Sabri Gürses, 2.Baskı, İleri yayınları, İstanbul, 2005.

${ }^{5}$ Delener, a.g.e. ; Schiffman ve Kanuk, 2009; Essoo and Dibb, 2004.

${ }^{6}$ Ali Çoskun, Çok kültürlülük, Çoğulculuk ve İslam. Din Antropolojisi. Ali Çoşkun (ed.). Kesit. İstanbul, 2014. ss. 177-216.

7 Beşir Hamidoğulları, İktisadî Sistemlerin Temelleri, Risale yayınları, İstanbul, 1998. s. 323.

${ }^{8}$ Hamza Bahadır Eser, "Dinin Siyasi Davranışlar Üzerindeki Etkisi: Antalya Örnek Olay Araștırması", Gazi Üniversitesi Íktisadi ve İdari Bilimler Fakültesi Dergisi, 14/3, 2012, ss. $104-106$.
}

Sayfa/Page | 187

IGU J. Soc. Sci., 4 (2), 2017, pp. $185-200$. 
Sayfa/Page | 188

İGÜ Sos. Bil. Derg.,

4 (2), 2017,

ss. $185-200$.

arasında geçen ve içinde kültürel ve sosyal bir takım davranış örüntülerini barındıran bir olgudur. ${ }^{9}$ Bu yüzden de kişinin toplumdaki konumu ve sınıfının belirlenmesine olanaklar sunan dirik bir örüntüdür. Buda tüketimin toplum içerisinde katmanlar yaratmasına ve sınıfsal ayrılıkları tetiklemesine sebep olmaktadır. Diğer bir deyişle, toplum içerisinde tüketim kültürünün gelişimi toplum içindeki sınıflanmalar ile biçimlenmektedir. Örneğin toplum içerisinde Aristokrasi veya dinsel sinıflar ön plana çıkıyorsa, toplumun tüketim kültürü de buna göre şekillenebilmektedir.10

Tarihsel süreçte dinin sahip olduğu değerler sistemi ile yan yana gelişen ve değişen tüketim olgusu, ihtiyaç duyulanın tatminden uzaklaşarak bu bağlamda arzuların tatmine doğru evirilmiştir. ${ }^{11}$ İlk tüketim kalıplarına bakıldığında, yapılan davranışların dinin etkisi ile yapılan yönlendirmeler sonucunda ortaya çıktığı görülmektedir. Buna göre, 17. Yüzyılın başlarında İngiltere'de iç savaşın ertesinde ilk üretim modellerinin ortaya çıkmasında dinsel olgular önemli rol oynamıştır. Kazancın sistematik, akla uygun ve barışçıl bir şekilde dağılımının önemli olduğu Püritenlik özellikle de tarım ve imalat kapitalizminin içinde yer alan burjuvaları önemli ölçüde etkilemiştir. ${ }^{12}$ Bir Protestanlık doktrini ve ibadet şekli olan Püritenliğe, göre elde edilen kazanç lüks yaşam için harcanmadan yeniden yatırıma yönlendirilmek üzere kullanıma ayrılmaktaydı. ${ }^{13}$ Böylelikle kapitalizmin ilk temelleri atılmış oldu. Yetişkin erkeklerin ve erkek çocuklarının kıyafetlerinin sadeliğinde ve evin sağlam inşa edilmesi fakat gösterişsiz renkler ve modeller ile dekore edilmesine kadar kurallar dizisi ile tüketim tercihlerini yönlendiriliyordu. ${ }^{14}$ Buna karşı aynı dönemde İngiliz püritarizminin karşısında, Protestanlık ve püritarizminden daha az etkilenmiş olan Fransa İspanya ve İtalya gibi ülkelerde moda, mücevher gösterişli ev dekorasyonları gibi israf sayılabilecek tüketim harcamaları çok daha fazlaydı. ${ }^{15}$

Dini eğilimi yüksek gruplar bağlamında tüketim olgusuna baktıktan sonra tüketiminin kapitalist metalar ile idol ve ikonların büyüsünü bozarak geldiği noktaya bakmak da gerekirse, gelinen noktada kapitalizme ait metalar kutsal ikon ve idollerin yerini almak sureti ile onların büyüsünü bozmuş, bu durum yazgının önceden belli olması ve kurtuluş günü gibi düşüncelerin var

9 Jean Baudrillard, Tüketim Toplumu, (çev. H, Deliceçaylı), Ayrıntı Yayınları, İstanbul, 2004. s. 46

10 Ünsal Oskay, 19. Yüzyıldan Günümüze Kitle İletişsimin Kültürel İşlevleri. Kurumsal Bir Yaklaşım. AÜ SBF Yay, Ankara 1983, ss. 175-178.

${ }^{11}$ Kaban, a.g.e., s. 11.

12 Robert Bocock, Tüketim, 3. Baskı. Dost Kitabevi Yayınları, Ankara, 2009, s. 21

13 George Ritzer, Büyüsü Bozulmuş Dünyayı Büyülemek, (çev. Şen Süer Kaya), Ayrıntı

Yayınları, İstanbul, 2000, s. 93.

${ }^{14}$ Cengiz Yanıklar, Tüketimin Sosyolojisi, Birey Yayıncıllk, İstanbul, 2006.

${ }^{15}$ Bocock, a.g.e., s. 22 . 
olmadığını bir dünya yaratmıştır. ${ }^{16}$ Modern tüketim fanteziler yaratarak, hiçbir zaman doyurulmaz bitmez tükenmez ihtiyaçlar ortaya koyarark sistematik bir devamlılık yaratmaktadır. ${ }^{17} \mathrm{Bu}$ durum dinin tüketimden ayrıştığı anlamına gelmemektedir, yalnızca paradigma değişimidir. Din tutumların belirlenmesinde önemli bir yere sahip olması nedeniyle hala tüketim üzerinde önemli bir etkiye sahip olduğu bilinmektedir.18

\subsection{Dinin Tüketici Davranışlarına Etkisi}

Dinin tüketiciler üzerindeki etkisi üzerine yabancı alan yazında yer alan konu ile başlıca çalışmalar şunlardır: İlk sayılabilecek çalışma, 1976 yılında Engel tarafından yapılmıştır. Engel bu çalışmasında, Brezilya'daki farklı dini grupların, ürün ve hizmet algılarının satın alma davranışlarına etkisini ortaya koymaya çalışmıştır.19 Hirschman (1983) çalışmasında, Yahudi , Katolik ve Protestan grupların hafta sonu eğlenicilerine yönelik tüketim kararlarında, konut seçimlerinde, ulaşım tercihlerinde ve evcil hayvan seçimlerinde önemli farklıklar olduğuna dikkat çekmiştir.20 Örneğin, Musevilik inancına sahip tüketiciler, daha çok yaratıcılık aramakta ve diğer 2 grup ile karşılaştırıldıklarında ise daha az marka mağaza sadakatine sahipler. Hirschmandan 3 yıl sonra yayınladığı çalışmasında Wikes ise, dini grupların ve dindarlığın tüketicilerin seçimlerini etkileyen, kanaat önderleri, kredi kartı kullanarak alışveriş yapma, riskten kaçınma ve yaşam doyumu gibi konular üzerinde etkisi olduğunu saptamıştır. ${ }^{21}$ Diğer taraftan bazı araştırmalarda ise çok dindar kişilerin satın alma kararlarında daha az dindar insanlara göre daha büyük risk alma eğiliminde olduklarını iddia etmiștir. ${ }^{22}$

Mokhlis, çalışmasında, çok dindar insanların daha az dindar insanlara oranla daha az ani satın alma kararı verdiklerini ve daha az dindar insanlara oranla fiyat ve kalite odaklı olduklarını ortaya çıkarmıştır. ${ }^{23}$ Choi, oldukça dindar Güney Koreli tüketiciler üzerine yaptığı çalışmasında, bu tüketicilerin daha az dindar ve inançsız tüketicilere oranla daha az marka, ürün ya da

${ }^{16}$ Kadir Zorlu, Modern Tüketim Tarihinde Tüketim Araştırmaları, Global Yayınları, Ankara, 2006, s. 107.

${ }^{17}$ Ritzer, a.g.e., ss. $96-97$.

${ }^{18}$ Bonne ... [ve öte.], 2009; Delener, 1990; Lada ... [ve öte.]., 2009; McDaniel and Burnett, 1990.

${ }^{19}$ James F. Engel, "Psychographic Research in a Cross Cultural Nonproduct Setting." NA-Advances in Consumer Research, (3), 1976, p. 100.

${ }^{20}$ Elizabeth C. Hirschman, "Religious Affiliation and Consumption Processes: An IInitial Paradigm", Research in Marketing, (6), 1983, pp. 131-170.

${ }^{21}$ Rober E. Wilkes \& John J. Burnett ve Roy Howell, "On The Meaning And Measurement of Religiosity in Consumer Research" Journal of the Academy of Marketing Science, 1986, 14(1), pp. 47-56.

22 Delener, a.g.e.

${ }^{23}$ Safiek Mokhlis, "The Effect of Religiosity on Shopping Orientation: An Exploratory Study in Malaysia" Journal of American Academy of Business, 9.1, 2006, pp. 64-74.

Sayfa/Page | 189

IGU J. Soc. Sci., 4 (2), 2017, pp. $185-200$. 
Sayfa/Page | 190

İGÜ Sos. Bil. Derg.,

4 (2), 2017,

ss. $185-200$.

mağaza değiştirme eğilimden olduklarını saptamıștır. ${ }^{24}$ Bilgin ise, etnografik bir araştırma ile sanayisi az gelişmiş Türkiye gibi bir ülkede, İslami dini ideolojinin marka anlamları konusunda düşük gelirli tüketici grubu nasıl bilgilendirdiğini incelemişlerdir. ${ }^{25}$

Yerli alan yazında konu ile ilgili az sayıda çalışma bulunmaktadır. 2012 yılında Çubukcuoğlu ve Haşıloğlu tarafından kaleme alınan çalışmada, tüketicilerin dindarlık seviyelerin ile onların satın alma davranışlarına ait birçok faktör arasında anlamlı ilişki saptanmıştır. ${ }^{26}$ Eser, 2014 yllındaki çalışması ile dinin siyasal tutumların şekillenmesinde etkisi olduğu sonucuna ulaşmıştır. ${ }^{27}$ Son olarak konu ile ilgili 2012 yılında Köroğlu tarafından tüketim olgusu dindarlık ekseninde ele alındığı bir doktora tezi yazılmıștır. ${ }^{28}$

Yapılan araştırmalar şunu göstermiştir ki; eğer bir kişi inançlı ise bu durumun onun davranışlarını etkilediği bilinmektedir ${ }^{29}$ Bazı çalışmalar özellikle semboller ve ritüellere odaklanmıştır. Çünkü dini değerler ve sahip olunan inançlar insan davranışlarını, sembolik değerler ve ritüeller aracıllğ etkilemektedir. Örneğin evlilikler, cenaze törenleri gibi gelenekler dinin etkisi ile şekillenir, organ bağışı, evlilik öncesi cinsellik gibi toplumsal konular ile ilgili kamuoyunu etkiler. Kişilerin günlük yaşamlarında neyin serbest (helal), neyin yasak (haram) olduğunu belirler. ${ }^{30}$

Din tüketici davranışlarını sadece satın alma veya almama gibi tek düze eylemlerle biçimlendirmez. Din eksenli ortaya çıkan davranışlarda derin etkileri olan birçok faktör bulunmaktadır. Bunun temel nedeni ise dinin, tutumların belirlenmesinde önemli bir yere sahip olmasıdır. ${ }^{31}$ Belirli dine mensup kişilerin sahip olduğu yükümlülükler bulunmaktadır, dini kurallar gereği kullanmasının ya da yemesinin yasak olduğu ürünler, örneğin Müslüman inancına sahip kişilerin domuz ürünleri yememesi gibi ${ }^{32}$; Neyin yasak neyin serbest olduğunu belirleyerek, tutum davranışları yönlendiren

${ }^{24}$ Youngtae Choi, "Religion, Religiosity, and South Korean Consumer Switching Behaviors", Journal of Consumer Behaviour, 9(3), 2010, pp. 157-171.

${ }^{25}$ Elif İzberk Bilgin "Infidel Brands: Unveiling alternative meanings of global brands at the nexus of globalization, consumer culture, and Islamism", Journal of Consumer Research, 39(4), 2012, pp. 663-687.

${ }^{26}$ Mehmet Emre Çubukçuoğlu, Selçuk Burak Haşıloğlu, "Dindarlık Olgusunun Satın alma Davranışı Faktörleri Üzerinde Etkisi" Tüketici ve Tüketim Araştırmaları Dergisi, 4/ 1.(1), 2012, s.18.

${ }^{27}$ Eser, a.g.e.

${ }^{28}$ Zehra Köroğlu, Tüketim Kültürü ve Din. Gümüşhane Üniversitesi Yayınları, 2012.

${ }^{29}$ Nizar Souiden \& Yosr Jabeur, "The impact of Islamic beliefs on consumers' attitudes and purchase intentions of life insurance". International Journal of Bank Marketing, 33, (4), 2015, 423-441

${ }^{30}$ Hamza Khraim, "Measuring religiosity in consumer research from Islamic perspective", International Journal of Marketing Studies, 2, 2), 2010, 166-179.

${ }^{31}$ Bonne ... [ve öte.], 2009; Delener, 1990; Lada ... [ve öte.], 2009; McDaniel and Burnett, 1990.

32 Mokhlis, a.g.e. 
din bu yolla tüketici davranışlarını etkilemektedir.33. Bununla birlikte bazı araştırmalar bu etkinin kişilere göre değiş̧enlik gösterdiğini ortaya koymuştur. ${ }^{34}$ Ayrıca tek tanrılı dinlerin (İslamiyet, Hristityanlık ve Musevilik gibi), tüketici davranışlarına etkisi çok tanırılı dinlere oranla çok daha fazladır. Bu üç semavi dinin inanları farklı derecelerde, kıyafet, diyet, iş ilişkileri gibi hayatının çok farklı yönlerine dokunan birtakım kuralları izlemeleri gerekliliği de bilinmektedir. ${ }^{35}$

\section{Araştırma Modeli ve Hipotezi}

$\mathrm{Bu}$ araştırmanın amacı dini hissetme düzeyinin tüketici karar verme süreçlerinde ne gibi etkileri olduğunu tespit etmektir. Bunun için gençlerin dindarlık düzeyleri, tüketici karar verme davranışları ve demografik özellikleri göz önüne alarak kişilerde oluşan davranış değişikliği süreçlerinde hangi faktörlerin ne oranda etkili olduğu araştırılmıștır. Bu kapsamda araştırma modelimiz şu şekilde formüle edilmiştir;

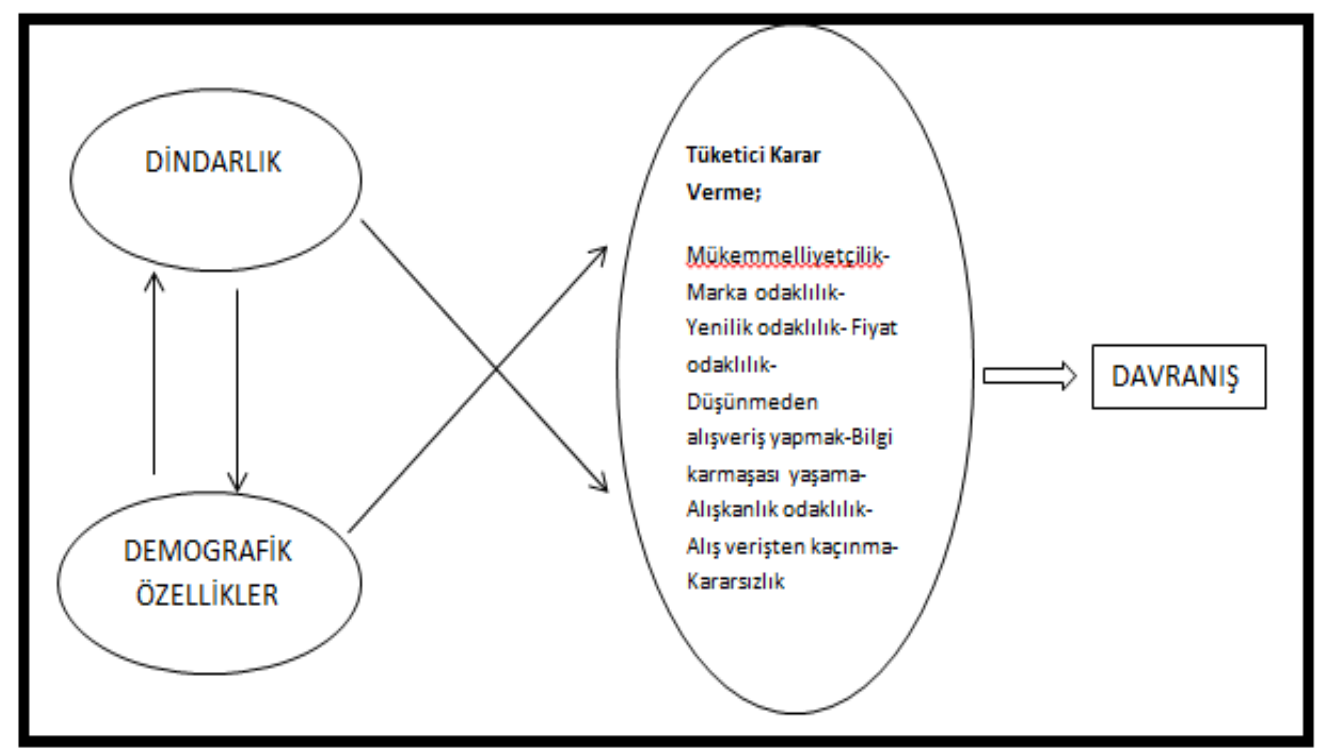

Bu bağlamda araştırmanın hipotezleri şu şekildedir;

H1:Dindarlık düzeyleri ile tüketici karar verme düzeyleri arasında anlamlı bir ilişki vardır.

H2:Dini hissetme düzeyleri tüketici davranışlarını etkiler.

H3:Demografik özellikler ile tüketici karar verme süreçleri arasında ilişki vardır.

\footnotetext{
${ }^{33} \mathrm{Kim}$... [ve öte.], 2004; Bonne ... [ve öte.], 2007; Mokhlis, 2006; Shaari ve Afitrin, 2010.

34 Delener, a.g.e.; Choi ... [ve öte.], 2010.

35 Djamchid Assadi, "Do Religions Influence Customer Behavior? Confronting Religious Rules And Marketing Concepts", Cahiers du CEREN, (5), 2003, 2-13.
}

Sayfa/Page | 191

IGU J. Soc. Sci., 4 (2), 2017, pp. $185-200$. 
Sayfa/Page | 192

İGÜ Sos. Bil. Derg.,

4 (2), 2017, ss. $185-200$.

\section{1. Örneklem}

Araştırmanın örneklemi belirlerken homojen bir örneklem yaratmak için farklı şehirlerde ve farklı kültürel özelliklere sahip gençleri içermesine dikkat edilmiştir. Bu bağlamda hem Türkiye'nin en büyük kenti olan İstanbul hem de küçük ölçekli kenti olan Tokat'ta bulunan ünivesite öğrencilerinden oluşan bir örneklem oluşturulmuştur. Örneklemin yaş aralığı 17-25 olup, toplam 361 kişiden oluşmaktadır. Örneklemin \%55,7 (201) kadın, \% 44,3 (160) erkektir.

\subsection{Araştırma Araçları}

Araştırmanın hipotezlerini test etmek amacıyla iki ölçek kullanılmıştır. Birincisi Yapıcı (2006) tarafından geliştirilen17 maddelik "Üniversiteli Gençlerin Dini Hissetme Düzeyi" ölçeği. İkincisi ise Sprolls \& Kendall (1986) tarafından geliştirilen Tüketici Tarzları Envanteridir (Consumer Styles Inventory). Bu ölçek Dursun ve diğerleri tarafından Türkçeye uyarlanmış ve “Tüketici Karar Verme Tarzları Ölçeği” (2013) olarak adlandırılarak geçerlilik güvenirlik testleri yapılmıştır. Ölçek 5'li likert tipte olup, 22 soru maddesinden oluşmaktadır. Tüketici Karar Verme Tarzları ölçeği mükemmelliyetçilik, marka odaklılık, yenilik odaklılık, fiyat odaklılık, düşünmeden alış veriş yapmak, bilgi karmaşası yaşama, alışkanlık odaklılık, alış verişten kaçınma ve kararsızlık alt faktörlerinden oluşmaktadır.

\subsection{Bulgular}

Tablo1: Araştırmaya katılanların demografik özellikleri

\begin{tabular}{|l|l|l|}
\hline & Frekans & Yüzde \\
\hline Cinsiyet & & \\
\hline Kadın & 201 & 55,7 \\
\hline Erkek & 160 & 44,3 \\
\hline Yaşamını Geçirdiği Yer & & \\
\hline Büyükşehir & 183 & 50,7 \\
\hline Küçük Şehir & 178 & 49,3 \\
\hline Alış Veriş Yapma Sıklığı & & \\
\hline Her gün & 8 & 2,2 \\
\hline Haftada birkaç kez & 49 & 13,6 \\
\hline Ayda birkaç kez & 89 & 24,7 \\
\hline İhtiyaç duydukça & 215 & 59,6 \\
\hline
\end{tabular}




\begin{tabular}{|c|c|c|}
\hline & Frekans & Yüzde \\
\hline \multicolumn{3}{|c|}{ İnternet Üzerinden Alıș Veriş Yapma } \\
\hline Hiç yapmadım & 114 & 31,6 \\
\hline Haftada birkaç kez & 17 & 4,7 \\
\hline Ayda birkaç kez & 59 & 16,3 \\
\hline Yılda birkaç kez & 171 & 47,4 \\
\hline \multicolumn{3}{|l|}{ Sosyal Ă̆ Hesabı } \\
\hline Hiç hesabım yok & 37 & 10,2 \\
\hline Yalnızca 1 & 87 & 24,1 \\
\hline $1-3$ & 143 & 39,6 \\
\hline 3 ve daha fazla & 94 & 26 \\
\hline \multicolumn{3}{|c|}{ İnternet Kullanma Sıklığı } \\
\hline Haftada birkaç saat & 22 & 6,1 \\
\hline Günde 1-2 saat & 66 & 18,3 \\
\hline Günde 3-4 saat & 113 & 31,3 \\
\hline Günde 4 saatten fazla & 160 & 44,3 \\
\hline \multicolumn{3}{|c|}{ İnterneti Kullanma Amacı } \\
\hline Eğlence & 262 & 72,6 \\
\hline Sosyalleşme & 196 & 54,3 \\
\hline Bilgi Edinme & 271 & 75,1 \\
\hline Alış veriş yapmak & 142 & 40,2 \\
\hline \multicolumn{3}{|l|}{ Aile Geliri } \\
\hline 1000 TL altı & 60 & 16,6 \\
\hline $1000-3000$ & 176 & 48,8 \\
\hline $3000-5000$ & 61 & 16,9 \\
\hline $5000-7000$ & 47 & 13 \\
\hline 7000-10000 & 10 & 2,8 \\
\hline 10000 üstü & 5 & 1,4 \\
\hline
\end{tabular}

Sayfa/Page | 193

IGU J. Soc. Sci.,

4 (2), 2017,

pp. $185-200$.

\subsection{Araștırmanın Hipotezlerinin Test Edilmesi}

Araştırmanın hipotezlerini test etmek amacıyla iki ölçek kullanılmıştır. Ölçeklerin güvenilirlik düzeyini tespit etmek için Cronbach's Alfa değerlerine bakılmıştır. Bu kapsamda “Üniversiteli Gençlerin Dini Hissetme Düzeyi” ölçeği 
Sayfa/Page | 194

İGÜ Sos. Bil. Derg.,

4 (2), 2017,

ss. $185-200$

Cronbach's Alfa:0,943 “Tüketici Tarzları Envanterinin” ölçeğinin Cronbach's Alfa:0,726 olarak tespit edilmiştir. Bu değerler ölçeklerin geçerlilik ve güvenirliği için yeterlidir.

Araştırmanın Birinci Hipotezi gençlerin dini hissetme düzeyleri ile tüketici karar verme düzeyleri arasında ilişki vardır. Bu kapsamda iki ölçek arasında pearson korelasyon testi yapıldı ve anlamlı bir sonuç çıkmıştır.

Tablo2: Tüketici Karar Verme Tarzları ile Dindarlık Arasındaki İlişki

\begin{tabular}{|l|l|l|l|}
\hline \multicolumn{2}{|c|}{} & Dini hissetme & $\begin{array}{l}\text { Tüketici karar } \\
\text { verme }\end{array}$ \\
\hline \multirow{4}{*}{ Dini hissetme düzeyi } & $\begin{array}{l}\text { Pearson } \\
\text { Correlation }\end{array}$ & 1 &, $209^{* *}$ \\
\cline { 2 - 4 } & Sig. (2-tailed) & &, 000 \\
\hline
\end{tabular}

Araştırmaya katılanların dindarlı düzeyleri ile tüketici davranışlarının alt faktörleri arasındaki ilişkiyi hesaplamak için pearson korelasyon testi yapılmıştır. Dini hissetme düzeyi ile Tüketici karar verme düzeyleri arasında 0,209 oranında pozitif yönlü anlamlı bir ilişki var.

Tablo3:Dindarlık ile tüketici davranışı alt faktörleri arasındaki ilişki

\begin{tabular}{|c|c|c|c|c|c|c|c|c|c|c|}
\hline & & $\begin{array}{l}\text { Mükem- } \\
\text { melliyet }\end{array}$ & $\begin{array}{l}\text { Marka - } \\
\text { fiyat } \\
\text { odakll- } \\
\text { lık }\end{array}$ & Moda & $\begin{array}{l}\text { Fiyat } \\
\text { odaklı }\end{array}$ & $\begin{array}{l}\text { Dikkat- } \\
\text { sizlik }\end{array}$ & $\begin{array}{l}\text { Alıșkan- } \\
\text { lık_mar- } \\
\text { ka_bağlı } \\
\text {-lığı }\end{array}$ & $\begin{array}{l}\text { Alışveriş- } \\
\text { ten kaçın- } \\
\text { ma }\end{array}$ & $\begin{array}{l}\text { Bilgi } \\
\text { karmasa- } \\
\text { Sl }\end{array}$ & $\begin{array}{l}\text { Karar } \\
\text { sizlık }\end{array}$ \\
\hline \multirow[t]{2}{*}{$\begin{array}{l}\text { Din- } \\
\text { darlık }\end{array}$} & $\begin{array}{l}\text { Pearson } \\
\text { Correlat } \\
\text { ion }\end{array}$ &, $142^{* *}$ & ,096 & ,200 & ,225** & -,052 & 038 & -009 & ,164 & 079 \\
\hline & $\begin{array}{l}\text { Sig. (2- } \\
\text { tailed) }\end{array}$ & 008 & ,069 & 000 & 000 & ,325 & 469 & 859 & 002, & 136 \\
\hline
\end{tabular}

Tablo 3'de yer alan verilere göre moda, fiyat odaklılık ve bilgi karmaşası alt faktörleri ile dindarlık arasında anlamlı ilișki söz konusudur.

Araştırmanın ikinci hipotezi olan dini hissetme düzeyinin tüketici davranışları üzerine etkisi olup olmadığını belirlemek amacıyla tek yönlü regresyon analizi yapılmıștır. 
Tablo4:Regresyon Analizi

\begin{tabular}{|l|l|l|l|l|l|l|}
\hline \multicolumn{2}{|l|}{ Model } & $\begin{array}{l}\text { Sum of } \\
\text { Squares }\end{array}$ & Df & Mean Square & F & Sig. \\
\hline \multirow{3}{*}{1} & Regression & 2,789 & 1 & 2,789 & 15,727 & $000^{\mathrm{b}}$ \\
\cline { 2 - 7 } & Residual & 61,186 & 345 & 177 & & \\
\cline { 2 - 7 } & Total & 63,976 & 346 & & & \\
\hline
\end{tabular}

Sayfa/Page | 195

Tablo4 de yer alan verilere göre regresyon analizi yapılabilir.

Tablo5: Ölçekler Arası Doğrusal Regresyon Testi

\begin{tabular}{|c|c|c|c|c|c|}
\hline \multirow[b]{2}{*}{ Model } & \multicolumn{2}{|c|}{$\begin{array}{l}\text { Unstandardized } \\
\text { Coefficients }\end{array}$} & \multirow{2}{*}{$\begin{array}{l}\text { Standardized } \\
\text { Coefficients } \\
\text { Beta }\end{array}$} & \multirow[b]{2}{*}{$\mathrm{t}$} & \multirow[b]{2}{*}{ Sig. } \\
\hline & B & Std. Error & & & \\
\hline $\begin{array}{l}1 \text { Dini Hissetme } \\
\text { Düzeyi }\end{array}$ & 2,807 & ,078 & & 36,014 & , 000 \\
\hline & ,090 & ,023 & 209 & 3,966 & ,000 \\
\hline
\end{tabular}

a. Dependent Variable: Tüketim

Tablo 5'de yer alan verilere göre; gençlerin dini hissetme düzeylerinin, tüketim alışkanlıkları üzerine etkisini araştırmak için doğrusal regresyon testi yapılmış ve dini hissetme düzeyinin tüketici karar verme süreçlerinde pozitif yönlü etkisi olduğu tespit edilmiştir.

Araştırmanın üçüncü hipotezi demografik özellikler ile tüketici davranışları arasında anlamlı ilişki vardır. Araştırmaya katılanların yaşam alanlarına göre anlamlı sonuçlar olup olmadığını anlamak için $t$ testi yapılmıştır. 
Sayfa/Page | 196

İGÜ Sos. Bil. Derg.,

4 (2), 2017, ss. $185-200$.

\begin{tabular}{|l|l|l|}
\hline \multirow{2}{*}{ Tüketim Alt Faktörleri } & \multicolumn{2}{l|}{$\begin{array}{l}\text { Yaşam Alanlarına } \\
\text { Göre }\end{array}$} \\
\cline { 2 - 3 } & $\mathrm{t}$ & $\mathrm{P}$ \\
\hline Mükemmelliyetçilik & $-4,719$ &, 000 \\
\hline Marka Fiyat Odaklııık & 5,254 &, 000 \\
\hline Moda &,- 196 &, 845 \\
\hline Fiyat Odaklı & $-2,569$ &, 011 \\
\hline Dikkatsizlik &, 931 &, 353 \\
\hline Alışkanlık Marka Bağlılı̆̆ı & $-5,643$ &, 000 \\
\hline Alışverişten Kaçınma &,- 153 &, 878 \\
\hline Bilgi Karmaşası & 1,195 &, 233 \\
\hline Kararsızlık & 2,239 &, 026 \\
\hline
\end{tabular}

Yaşam alanlarına göre Mükemmelliyetçilik, marka fiyat odaklılığı ve alışkanlık marka fiyat odaklılığı arasında anlamlı bir ilişki vardır.

\section{SONUÇ}

Din ve tüketici karar verme süreçleri ile ilgili literatürde çeşitli çalışmalar bulunmaktadır. Yurtdışında hem din ile ilgili disiplinler hem de tüketim üzerine çalışmalar yapan disiplinler bu alanda birçok çalışma yaparken ülkemizde bu tip çalışmalar yok denecek kadar azdır. Bu yüzdende konu ile ilgili hipotez geliştirmekten ziyade araştırma soruları oluşturularak konu yorumlanmaya çalışılmıştır. ${ }^{36} \mathrm{Bu}$ çalışma konu ile ilgili bir hipotez koyarak dini hissetme düzeyinin tüketici davranışları üzerindeki etkisini istatistiki olarak açıklamayı amaçlamıştır. Bu kapsamda yapılan araştırmalar sonucunda elde edilen verilerin normal dağılım göstermesinden dolayı bağımsız iki grup arasındaki ilişkiyi belirlemeye yönelik " $t$ " testi, ölçekler arasındaki ilişki tespit etmeye yönelik pearson korelasyonu ve ölçeklerin birbiri üzerindeki etkisini belirlemeye yönelik tek yönlü regresyon analizi yapılmıştır. $\mathrm{Bu}$ analizler sonucunda; Araştırmanın birinci hipotezi olan ölçekler arasındaki ilişkiyi tespit etmeye yönelik korelasyon testi yapılmış ve anlamlı sonuçlar bulunmuştur. Bu sonuç bu alanda yapılan diğer çalışmalar ile uyumluluk göstermektedir. ${ }^{37}$ Dindarlığın ne oranda tüketici davranışlarına etki ettiği ile ilgili yapılan regresyon analizi sonucunda; "Tüketici Karar

${ }^{36}$ Çubukçuoğlu \& Haşıloğlu, a.g.m., s.8

37 Çubukçuoğlu \& Haşıloğlu, 2012; Delener, N. 1994; Essoo, N. and Dibb, S. 2004; Syed

S. Alam, R. Mohd \& B. Hisham, 2011 
Verme $=2,807+0,90 *$ Dindarlık" düzeyinde bir etkisi olduğu tespit edilmiştir (H2).

Yapılan istatistiki değerlendirmeler sonucunda katılımcıların cinsiyet, internet kullanım alışkanlıkları ile tüketici davranışları arasında anlamlı bir ilişki bulunamazken, yaşam alanlarına göre tüketici davranışları arasında anlamlı ilişkiler tespit edilmiştir (H3). Ayrıca araştırmaya katılanların yaklaşık \%72,6'sı interneti eğlence amaçlı kullanırken alışveriş amaçlı kullananların oranı $\% 40,2$ dir.

Yapılan bu tip çalışmalar ile dindarlık ve tüketim arasında çok önemli ilişkiler olduğu tespit edilmiștir. Özellikle bireylerin tutum ve davranışlarını direk etkilediği bir çok çalışmada ortaya konmuştur. Bu yüzdende günümüzde firmalar tüketicilerin inançları ile markalarının yarattığı değerleri eşleştirme çabasına girmiştir. Böylelikle markalar ortak değerleri ve inançları içeren, ve tüketici ile organic bağ geliştiren hikayeler oluşturabilmektedirler. Buda tüketicinin sadakati ve memnuniyeti ile ilgili yeni faktörlerin ortaya çımasına sebep olmuştur. Artık günümüzde dinsel inançları temsil eden kahramanlar, ritüeller ve semboller markaların kendi hikayelerinde sıkça kullanılır hale gelmiştir.

İnsanların tüketici davranışlarını etkileyen bir diğer unsurda markanın itibarıdır. İnsanların dini inançları doğrultusunda hareket eden firmalar kendilerine yeni bir itibar kanalı yaratabilmektedir. Dinin tüketici davranışlarının etkisi ve buna bağlı olarak itibar yaratma sürecinde bankacılık sisteminde de kullanıldığı tespit edilmiştir.38. Buda dinin tüketim davranışlarına etki derecesinin davranışa dönüşme süeçlerini açıklamaktadır.

Konu ile ilgili yapılacak bundan sonraki çalışmalarda müşteri sadakatinin, itibarın ve memnuniyetinin dindarlık düzeyi ile ilişkisinin incelenmesi önerilmektedir.

\section{KAYNAKÇA}

ABOU-YOUSSEF, Mariam Mourad Hussein, Wael KORTAM, Ehab ABOUAISH, Noha EL-BASSIOUNY, "Effects of Religiosity on Consumer Attitudes Toward Islamic Banking in Egypt" International Journal of Bank Marketing 33 (6), 2015, pp. 786-807.

ALAM, Syed Shah, Rohani MOHD, and Badrul HISHAM. "Is religiosity an important determinant on Muslim consumer behaviour in Malaysia?", Journal of Islamic Marketing, 2(1), 2011, 83-96.

${ }^{38}$ Abou-Youssef... [et. al.], "Effects of Religiosity on Consumer Attitudes Toward Islamic Banking in Egypt", International Journal of Bank Marketing, 2015, 33(6), pp. 786-807.

Sayfa/Page | 197

IGU J. Soc. Sci., 4 (2), 2017, pp. $185-200$. 
Sayfa/Page | 198

İGÜ Sos. Bil. Derg.,

4 (2), 2017, ss. $185-200$.

ASSADI, Djamchid, "Do Religions Influence Customer Behavior? Confronting Religious Rules And Marketing Concepts", Cahiers du CEREN, 5, 2003, pp. 2-13.

BAUDRILlARD, Jean, Tüketim Toplumu, çev. H. Deliceçaylı, Ayrıntı Yayınları, İstanbul, 2004.

BOCOCK, Robert, Tüketim. 3. Baskı, Dost Kitabevi Yayınları, Ankara, 2009.

BONNE, Kairjn, Iris Vermeir, Florence Bergeaud-Blackler, Wim Verbeke, "Determinants of halal meat consumption in France", British Food Journal. 109, (5), 2007, 367-386.

CHOI, Youngtae, Religion, religiosity, and South Korean consumer switching behaviors. Journal of Consumer Behaviour. 9(3), 2010, pp. 157171.

CHOI, Youngtae, Rahul KALE, \& Jongkuk SHIN, "Religiosity and consumers' use of product information source among Korean consumers: an exploratory research", International Journal of Consumer Studies. 34, (1), 2010, pp. 61-68.

ÇOŞKUN, Ali, Çok kültürlülük, Çoğulculuk ve İslam. Din Antropolojisi. Ali Çoşkun (ed.). Kesit. İstanbul. 2014, ss. 177-216.

ÇUBUKÇUOĞLU, Mehmet Emre \& Selçuk Burak HAŞILOĞLU, Dindarlık Olgusunun Satın alma Davranışı Faktörleri Üzerinde Etkisi. Tüketici ve Tüketim Araştırmaları Dergisi. 4/ (1), 2012, ss. 1-18.

DELENER, Niyazi, "The Effects of Religious Factors on Perceived Risk in Durable Goods Purchase Decisions" Journal of Consumer Marketing, 7(3), 1990, pp. 27-38.

DELENER, Niyazi, "Religious contrasts in consumer decision behaviour patterns: their dimensions and marketing implications", European Journal of Marketing. 28, (5), 1994, pp. 36-53.

DURSUN, İnci, Ümit ALNIAÇIK \& Ebru TÜMER KABADAYI, "Tüketici Karar Verme Tarzları Ölçeği: Yapısı ve Boyutları" Uluslararası Yönetim İktisat ve İşletme Dergisi, 9(19), (2013), ss. 293-304.

EL-BASSIOUNY, Noha, "The one billion plus marginalization: toward a scholarly understanding of Islamic consumers", Journal of Business Research. 67, (2), 2014, pp. 42-49.

ENGEL, James, " Psychographic research in a cross cultural non product setting." Advances in Consumer Research, 3(1). 1976, pp. 98-101. 
ESER, Hamza Bahadır, "Dinin Siyasi Davranışlar Üzerindeki Etkisi: Antalya Örnek Olay Araştırması" Gazi Üniversitesi İktisadi ve İdari Bilimler Fakültesi Dergisi. 14/3, 2012, ss. 97-136.

ESSOO, Nittin and Sally DIBB, "Religious influences on shopping behaviour: an exploratory study", Journal of Marketing Management, Vol. 20, 2004, pp. 683-712.

HAMİDOĞULLARI, Beşir, İktisadî Sistemlerin Temelleri. Risale Yayınları, İstanbul. 1988.

HIRSCHMAN, C. Elizabeth, "Religious Affiliation And Consumption Processes: An Initial Paradigm” Research in Marketing, (6), 1983, pp. 131170.

IZBERK, E. Bilgin, "Infidel Brands: Unveiling Alternative Meanings of Global Brands at The Nexus of Globalization, Consumer Culture, And Islamism" Journal of Consumer Research, 39(4), 2012, pp. 663-687.

KHRAIM, Hamza, "Measuring Religiosity in Consumer Research From Islamic Perspective", International Journal of Marketing Studies. 2, (2), 2010, pp. 166-179.

FAM Kim Shyan, David S. WALLER, and B. Zafer ERDOĞAN, "The influence of religion on attitudes towards the advertising of controversial products", European Journal of Marketing, 38, 5(6), 2004, pp. 537-555.

KÖROĞLU, Zehra, Tüketim Kültürü ve Din. Gümüşhane Üniversitesi Yayınları, Gümüşhane, 2012.

LADA, Suddin, Geoffrey Harvey TANAKINJAL, and Hanudin AMIN, "Predicting intention to choose halal products using theory of reasoned action", Internatioanl Journal of Islamic and Middle Eastern Finance and Management, 2,(1), 2008, pp. 66-76.

MCDANIEL W. Stephen \& John J. BURNETT, "Consumer Religiosity and Retail Store Evaluative Criteria", Journal of the Academy of Marketing Science. 18, (2), 1990, pp. 101-112.

MOKHLIS, Safiek, "The effect of religiosity on shopping orientation: an exploratory study in Malaysia", Journal of American Academy of Business. 9, (1) , 2006, pp. 64-74.

OSKAY, Ünsal, 19. Yüzyıldan Günümüze Kitle İletişimin Kültürel İşlevleri. Kurumsal Bir Yaklaşım. AÜ SBF Yay, Ankara, 1983.

ÖKTEM, Niyazi, Laiklik Din ve Alevilik Yazıları. Der Yayınları. İstanbul, 1995.

RITZER, George, Büyüsü Bozulmuş Dünyayı Büyülemek, (çev. Şen Süer Kaya), İstanbul. Ayrıntı Yayınları. 2000.

Sayfa/Page | 199 IGU J. Soc. Sci., 4 (2), 2017, pp. $185-200$. 
Sayfa/Page | 200

İGÜ Sos. Bil. Derg.,

4 (2), 2017,

ss. $185-200$.

SCHIFFMAN, G. Leon and Leslie Lazar KANUK, Consumer Behavior, Pearson Education, Harlow. 2009.

SHAARI, Jamal Abdul Nassir, and N. S. Mohd ARIFIN, "Dimension of Halal Purchase Intention: A Preliminary Study, International Review of Business Research Papers. 6, (4), 2010, pp. 444-456.

SOMBART, Werner, Kapitalizm ve Yahudiler, (çev. Sabri Gürses) (2.Baskı). İstanbul: İleri Yayınları.2005.

SOUIDEN, Nizar, and Yosr JABEUR, "The impact of Islamic Beliefs on Consumers' Attitudes And Purchase Intentions of Life Insurance" International Journal of Bank Marketing. 33, (4), 2015, pp. 423-441.

WILKES, Robert E., John J. BURNETT, and Roy D. HOWELL, "On the meaning and measurement of religiosity in consumer research." Journal of the Academy of Marketing Science, 14 (1), 1986, pp. 47-56.

YANIKLAR, Cengiz, Tüketimin Sosyolojisi. Birey Yayıncılık, İstanbul. 2006.

\section{Summary}

The developments in communication technologies and the effects of globalization and consumer behavior are rapidly changing and developing. Recent studies have shown that religious values directly affect daily consumption habits. In particular, companies are focused on creating brands that put religious values at the forefront. This study is an important study in determining the religious dimension of the factors affecting customer satisfaction and loyalty in hypercarbia environment. When we look at the studies done in Turkey, it is seen that studies conducted in the nature of an area survey as a hypothesis. That is why the basic reason is that there is not much work on the field. This work will then form the basis for the hypotheses to be made.

Within the scope of the study, regression tests were conducted to determine the extent of the effect between consumer decision-making styles and religiousness. In this context, our work is separated from the work done in Turkey, and the literature adds a new perspective. As a result of the statistical analyzes made, the level of the effect of religiousness on consumption behavior is discussed. As a result, significant relationships between religion and consumer behavior were identified. 